\title{
The Growth of Roots and Green Leaves of Allium cepa L. after the Removal of Different Parts of the Bulb
}

\author{
A. Yu. Budantsev
}

Institute of Theoretical and Experimental Biophysics, Russian Academy of Sciences, Pushchino Department, Lomonosov's Moscow State University, Moscow, Russia.

Email: budantsev@mail.ru

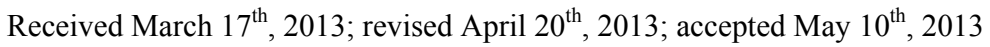

Copyright (C) 2013 A. Yu. Budantsev. This is an open access article distributed under the Creative Commons Attribution License, which permits unrestricted use, distribution, and reproduction in any medium, provided the original work is properly cited.

\begin{abstract}
The dynamics of the growth of roots and leaves of the Allium cepa L. after the mechanical removal of a part of the root system or the bulb was studied. It was shown that, after surgical interference, the potency for organogenesis is retained, although it is weakened.
\end{abstract}

Keywords: Organogenesis; Bulbs of Allium Cepa; Removal of Bulb and Root Parts; Growth of Roots and Leaves

\section{Introduction}

The bulbs of Allium cepa L. contain biologically active compounds necessary for the development of the vegetative elements of the collum (roots and leaves). The activation of physiological processes in the bulb triggers metabolic processes vital for the formation of the root system and above-ground plant organs.

The biochemistry of bulbs of the genus Allium was studied mainly from the viewpoint of their practical use as natural row materials for medicinal forms in the phytotherapy and homeopathy [3-5]. In addition, onion is a valuable agricultural crop; therefore, the gustatory and aromatic features of green leaves and bulbs were intensively investigated. It was shown that the biochemistry of bulbs and leaves that determines their consumer's properties depend on soils, climatic, and agrotechnical conditions of cultivation and storage [6,7]. There are a number of papers concerned with the morphology, biochemistry, and histochemistry of the structure of some members of the Allium genus [1,2]. In these papers there are almost no data on the mechanisms of interaction of the bulb and vegetative elements of the collum during the initiation of the organogenesis of the root system and the epigeal part of onion.

In the present work, we analyzed the dynamics of growth of vegetative organs (roots and green leaves of the Allium cepa L.) after mechanical removal of a part of the root system and a part of the bulb.

\section{Materials and Methods}

Bulbs of the onion (Allium cepa L.) of the first-year crop, variety Stuttgarter Riesen (Plantuitjes, Holland), 16 - 23 $\mathrm{mm}$ in diameter were used. In all, 270 bulbs (19 series of experiments) were used. Bulbs were freed from dry external scales and old roots and germinated in tap water in the darkness at $+24^{\circ} \mathrm{C}-27^{\circ} \mathrm{C}$. After $24 \mathrm{~h}$, bulbs with germinated roots $(6-10-\mathrm{mm}$ long) were transferred to test tubes with tap water. In experimental samples, a part of the root system or of the bulb was removed. Bulbs were photographed every $24 \mathrm{~h}$ by a digital camera PowerShot A650IS (Canon, Japan). The length of roots and leaves was measured using the program PhotoM (http://t_lambda.chat.ru). The increment of roots and leaves $(V, \mathrm{~mm} / \mathrm{h})$ was calculated by the formula: $V=$ $\left(L_{\mathrm{t}+\mathrm{tx}}-L_{\mathrm{t}}\right) / t x$, where $L_{\mathrm{t}}$ is the length of roots and leaves at the starting time $t, L_{\mathrm{t}+\mathrm{tx}}$ is the length at the time of the next measurement, and $t x$ is the time between the increment measurements $(24 \mathrm{~h})$. The statistical analysis was performed using the program Statistica 6.0 (StatSoft. Inc., USA, http://www.statsoft.com).

\section{Results}

1) Growth of roots and green leaves after the removal of a part of the root system.

In these experiments, a greater part of roots was removed; one, two, or three roots were left. The results of one series of experiments are presented in Table 1. It is seen that 
Table 1. Dynamics of the growth of roots and leaves of the onion Allium cepa $\mathrm{L}$. after the removal of a part of the root system.

\begin{tabular}{|c|c|c|c|c|c|}
\hline \multirow{2}{*}{\multicolumn{2}{|c|}{ Hour of experiment }} & \multicolumn{4}{|c|}{$\mathrm{M} \pm \mathrm{m}$ (root and leaf length. mm) } \\
\hline & & \multirow{2}{*}{$\begin{array}{c}\begin{array}{c}\text { Control } \\
(\mathrm{n}=10)^{*}\end{array} \\
6.9 \pm 0.4\end{array}$} & \multirow{2}{*}{$\begin{array}{c}\begin{array}{c}1 \text { root } \\
(\mathrm{n}=3)\end{array} \\
6.5 \pm 0.4\end{array}$} & \multirow{2}{*}{$\begin{array}{l}\begin{array}{l}2 \text { roots } \\
(\mathrm{n}=6)\end{array} \\
6.3 \pm 0.6\end{array}$} & \multirow{2}{*}{$\begin{array}{c}3 \text { roots } \\
(\mathrm{n}=6)\end{array}$} \\
\hline 0 & $\mathrm{R}^{* *}$ & & & & \\
\hline \multirow{2}{*}{24} & $\mathrm{R}$ & $\begin{array}{c}22.9 \pm 2.4 \\
\mathbf{0 . 4 2}^{* * * *}\end{array}$ & $\begin{array}{c}15.0 \pm 3.1 \\
\mathbf{0 . 4 2}\end{array}$ & $\begin{array}{c}16.5 \pm 1.2 \\
\mathbf{0 . 3 1}\end{array}$ & $\begin{array}{c}15.1 \pm 1.8 \\
\mathbf{0 . 3 7}\end{array}$ \\
\hline & $\mathrm{L}^{* *}$ & $4.6 \pm 0.3$ & $9.1 \pm 3.7$ & $7.5 \pm 0.9$ & $4.7 \pm 0.8$ \\
\hline \multirow{2}{*}{48} & $R$ & $\begin{array}{c}42.8 \pm 0.8 \\
\mathbf{0 . 4 5}\end{array}$ & $\begin{array}{c}27.5 \pm 4.8 \\
\mathbf{0 . 0 7}\end{array}$ & $\begin{array}{c}30.0 \pm 1.7 \\
\mathbf{0 . 5 1}\end{array}$ & $\begin{array}{c}20.8 \pm 3.5 \\
\mathbf{0 . 3 8}\end{array}$ \\
\hline & $\mathbf{L}$ & $\begin{array}{c}13.1 \pm 0.8 \\
\mathbf{0 . 3 5}\end{array}$ & $\begin{array}{c}12.3 \pm 7.4 \\
\mathbf{0 . 1 3}\end{array}$ & $\begin{array}{c}9.7 \pm 1.8 \\
\mathbf{0 . 0 9}\end{array}$ & $\begin{array}{c}5.4 \pm 0.2 \\
\mathbf{0 . 0 3}\end{array}$ \\
\hline \multirow{2}{*}{72} & K & $\begin{array}{c}57.5 \pm 0.8 \\
\mathbf{0 . 4 9}\end{array}$ & $\begin{array}{c}38.7 \pm 7.6 \\
\mathbf{0 . 1 7}\end{array}$ & $\begin{array}{c}41.9 \pm 2.2 \\
\mathbf{0 . 5 8}\end{array}$ & $\begin{array}{c}23.8 \pm 5.7 \\
\mathbf{0 . 2 8}\end{array}$ \\
\hline & Л & $\begin{array}{c}30.6 \pm 2.8 \\
\mathbf{0 . 7 3}\end{array}$ & $\begin{array}{c}19.7 \pm 2.7 \\
\mathbf{0 . 3 1}\end{array}$ & $\begin{array}{c}15.8 \pm 4.8 \\
\mathbf{0 . 2 5}\end{array}$ & $\begin{array}{c}6.2 \pm 0.2 \\
\mathbf{0 . 0 3}\end{array}$ \\
\hline \multirow{2}{*}{96} & $\mathrm{R}$ & $>60$ & $\begin{array}{c}47.7 \pm 8.2 \\
\mathbf{0 . 3 3}\end{array}$ & $\begin{array}{c}57.5 \pm 1.2 \\
\mathbf{0 . 3 3}\end{array}$ & $\begin{array}{c}39.2 \pm 3.1 \\
\mathbf{0 . 4 3}\end{array}$ \\
\hline & $\mathrm{L}$ & $>60$ & $\begin{array}{c}36.4 \pm 27.4 \\
\mathbf{0 . 6 9}\end{array}$ & $\begin{array}{c}35.4 \pm 11.3 \\
\mathbf{0 . 8 2}\end{array}$ & $\begin{array}{c}17.3 \pm 3.3 \\
\mathbf{0 . 4 6}\end{array}$ \\
\hline
\end{tabular}

$\mathrm{n}$, number of measurements; ${ }^{* *} \mathrm{R}$, root; $\mathrm{L}$, leaf; ${ }^{* * *}$ absolute root length $(\mathrm{M} \pm \mathrm{m})$; increment $(\mathrm{V}, \mathrm{mm} / \mathrm{h}$. semibold type).

the absolute increment in the growth of roots in the control significantly exceeds the growth of roots after the surgical intervention. There is no correlation between the number of roots left and the dynamics of their growth. However, it is evident that the decrease in the number of the roots and, probably, the operation itself lead to a reduction of root increment.

After roots were removed the growth of new roots was observed; newly formed roots were removed every day. In one series of experiments, delete one root was left and new roots were not removed, from 2 to 13 additional roots developed.

The absolute increment in the length of the leaf was significantly diminished. No direct correlation between the increment in leaf growth and the number of roots left was observed over a period of four to five days.

2) Growth of roots and green leaves after the removal of a part of the bulb.

In another series experiments, the upper half of the bulb, two thirds of the bulb, and almost the whole bulb (the collum with the base of juicy leaves was left) were removed. In some experiments, in addition to a part of the bulb, a part of the root system was removed (one, two, or three roots were left). The results of one of these series of experiments are presented in Tables $\mathbf{2}$ and $\mathbf{3}$.

The absolute increment in the root length after the removal of the upper half of the bulb in the experiment and control was almost equal. After the removal of the upper two thirds of the bulb, an insignificant decrease in the absolute increment in the root length occure. It should be noted that the differences were not clearly defined on the first day and somewhat increase at the close of observations. The removal of almost the entire bulb led to a significant decrease in the absolute increment of root length.

The removal of the half of the bulb led to a decrease in the absolute increment of the green leaf length. This may be associated with the mechanical injury to the leaf primordia. After the removal of two thirds of the bulb, the growth of the leaf decreased almost to zero and in experiments in which collums were retained, no growth of the green leaf was observed (Table 2).

\section{Discussion}

In the present work, we analyzed the dynamics of growth of roots and green leaves of Allium cepa L. after mechanical removal of a part of the root system and the bulb.

The results of the experiments indicated that, with the disturbance of the initial quantitative roots-bulb relationship, the potency (capacity) for ontogenesis is retained, though it is weakened. After the initiation of growth processes in roots in the control, the root growth continues even though the bulb mass is strongly reduced. The exchange of metabolites between growing roots and the bulb upon a decrease in the number of roots or in the bulb size remains sufficient to provide the activity of the apical root meristem. 
Table 2. Dynamics of the growth of roots and leaves of the onion Allium cepa L. after the removal of a part of the bulb.

\begin{tabular}{|c|c|c|c|c|c|c|}
\hline \multirow{2}{*}{$\begin{array}{l}\text { Part of the bulb } \\
\text { that was left }\end{array}$} & & \multicolumn{5}{|c|}{ Time of experiment (h) } \\
\hline & & 0 & 24 & 48 & 72 & 96 \\
\hline \multirow{2}{*}{$\begin{array}{c}\text { Control } \\
\text { (the whole bulb) }\end{array}$} & $\begin{array}{c}\mathrm{R} \\
(\mathrm{n}=10)\end{array}$ & $13.2 \pm 0.5$ & $\begin{array}{c}29.2 \pm 0.7 \\
\mathbf{0 . 6 7}\end{array}$ & $\begin{array}{c}41.7 \pm 0.9 \\
\mathbf{0 . 5 2}\end{array}$ & $\begin{array}{c}49.0 \pm 0.9 \\
\mathbf{0 . 3 0}\end{array}$ & $\begin{array}{c}56.1 \pm 1.4 \\
\mathbf{0 . 2 9}\end{array}$ \\
\hline & $\begin{array}{c}\mathrm{L} \\
(\mathrm{n}=2)\end{array}$ & $5.0 \pm 3.3$ & $\begin{array}{c}14.4 \pm 0.7 \\
0.40\end{array}$ & $\begin{array}{c}25.1 \pm 5.1 \\
0.43\end{array}$ & $\begin{array}{c}36.0 \pm 4.7 \\
0.45\end{array}$ & $\begin{array}{c}46.1 \pm 0.4 \\
0.42\end{array}$ \\
\hline \multirow{2}{*}{$1 / 2$} & $\begin{array}{c}\mathrm{R} \\
(\mathrm{n}=15)\end{array}$ & $12.2 \pm 0.4$ & $\begin{array}{l}29.3 \pm 0.6 \\
\mathbf{0 . 7 1}\end{array}$ & $\begin{array}{c}43.1 \pm 1.2 \\
\mathbf{0 . 5 7}\end{array}$ & $\begin{array}{c}52.4 \pm 1.9 \\
\mathbf{0 . 3 9}\end{array}$ & $\begin{array}{c}61.4 \pm 2.0 \\
\mathbf{0 . 3 7}\end{array}$ \\
\hline & $\begin{array}{c}\mathrm{L} \\
(\mathrm{n}=3)\end{array}$ & - & - & $4.7 \pm 1.0$ & $\begin{array}{c}9.9 \pm 2.5 \\
\mathbf{0 . 2 2}\end{array}$ & $\begin{array}{c}16.7 \pm 4.7 \\
\mathbf{0 . 2 8}\end{array}$ \\
\hline \multirow{2}{*}{$1 / 3$} & $\begin{array}{c}\mathrm{R} \\
(\mathrm{n}=15)\end{array}$ & $8.8 \pm 0.7$ & $\begin{array}{l}22.1 \pm 1.1 \\
\mathbf{0 . 5 5}\end{array}$ & $\begin{array}{c}29.3 \pm 2.0 \\
\mathbf{0 . 3 0}\end{array}$ & $\begin{array}{c}38.4 \pm 2.9 \\
\mathbf{0 . 3 8}\end{array}$ & $\begin{array}{c}42.7 \pm 2.9 \\
\mathbf{0 . 1 8}\end{array}$ \\
\hline & $\begin{array}{c}\mathrm{L} \\
(\mathrm{n}=3)\end{array}$ & - & - & $1.8 \pm 0.3$ & $\begin{array}{c}4.1 \pm 0.1 \\
\mathbf{0 . 0 9}\end{array}$ & $\begin{array}{c}3.3 \pm 2.2 \\
-\end{array}$ \\
\hline \multirow{2}{*}{ Collum } & $\begin{array}{c}\mathrm{R} \\
(\mathrm{n}=10)\end{array}$ & $9.8 \pm 0.5$ & $\begin{aligned} 7.8 & \pm 0.5 \\
& -\end{aligned}$ & $\begin{array}{c}8.0 \pm 0.4 \\
-\end{array}$ & $\begin{array}{c}8.7 \pm 0.5 \\
\quad-\end{array}$ & $\begin{array}{c}9.7 \pm 1.3 \\
-\end{array}$ \\
\hline & $\begin{array}{c}\mathrm{L} \\
(\mathrm{n}=2)\end{array}$ & - & - & - & - & - \\
\hline
\end{tabular}

Abbreviations, see Table 1.

Table 3. Dynamics of the growth of roots of the onion Allium cepa L. after the removal of a part of the bulb and roots.

\begin{tabular}{|c|c|c|c|c|c|c|}
\hline \multirow{2}{*}{$\begin{array}{c}\text { Part of the bulb that } \\
\text { was left }\end{array}$} & \multirow{2}{*}{$\begin{array}{l}\text { Variants of } \\
\text { experiment }\end{array}$} & \multicolumn{5}{|c|}{ Time of experiment $(\mathrm{h})$} \\
\hline & & 0 & 24 & 48 & 72 & 96 \\
\hline \multirow{4}{*}{$1 / 2$} & $\begin{array}{l}\text { Control }^{*} \\
(\mathrm{n}=10)\end{array}$ & $7.6 \pm 0.2$ & $\begin{array}{c}16.4 \pm 0.7 \\
\mathbf{0 . 3 7}\end{array}$ & $\begin{array}{l}27.2 \pm 1.1 \\
\quad \mathbf{0 . 4 5}\end{array}$ & $\begin{array}{l}38.0 \pm 2.6 \\
\mathbf{0 . 4 5}\end{array}$ & $>60$ \\
\hline & $\begin{array}{l}1 \text { root } \\
(\mathrm{n}=3)\end{array}$ & $7.6 \pm 0.7$ & $\begin{array}{c}15.8 \pm 1.7 \\
\mathbf{0 . 3 4}\end{array}$ & $\begin{array}{c}24.9 \pm 3.4 \\
\mathbf{0 . 3 8}\end{array}$ & $\begin{array}{c}33.2 \pm 6.7 \\
\mathbf{0 . 3 4}\end{array}$ & $\begin{array}{c}50.4 \pm 4.2 \\
\mathbf{0 . 7 2}\end{array}$ \\
\hline & $\begin{array}{l}2 \text { roots } \\
(\mathrm{n}=6)\end{array}$ & $4.8 \pm 0.2$ & $\begin{array}{c}10.3 \pm 1.2 \\
\mathbf{0 . 2 3}\end{array}$ & $\begin{array}{c}19.8 \pm 2.3 \\
\mathbf{0 . 3 9}\end{array}$ & $\begin{array}{c}34.0 \pm 2.3 \\
\mathbf{0 . 5 9}\end{array}$ & $\begin{array}{c}54.0 \pm 3.5 \\
\mathbf{0 . 8 3}\end{array}$ \\
\hline & $\begin{array}{l}3 \text { roots } \\
(n=6)\end{array}$ & $6.3 \pm 0.4$ & $\begin{array}{c}13.5 \pm 1.8 \\
\mathbf{0 . 3 0}\end{array}$ & $\begin{array}{c}22.3 \pm 4.1 \\
\mathbf{0 . 3 7}\end{array}$ & $\begin{array}{c}33.6 \pm 7.0 \\
\mathbf{0 . 4 7}\end{array}$ & $\begin{array}{l}46.7 \pm 5.8 \\
\mathbf{0 . 5 5}\end{array}$ \\
\hline \multirow{4}{*}{$1 / 3$} & $\begin{array}{l}\text { Control } \\
(\mathrm{n}=10)\end{array}$ & $9.6 \pm 0.5$ & $\begin{array}{c}22.0 \pm 1.2 \\
\mathbf{0 . 5 2}\end{array}$ & $\begin{array}{l}35.5 \pm 1.2 \\
0.56\end{array}$ & $\begin{array}{c}51.3 \pm 0.3 \\
\quad \mathbf{0 . 6 6}\end{array}$ & $>60$ \\
\hline & $\begin{array}{l}1 \text { root } \\
(n=3)\end{array}$ & $8.8 \pm 0.1$ & $\begin{array}{c}22.9 \pm 1.0 \\
\mathbf{0 . 5 9}\end{array}$ & $\begin{array}{c}31.2 \pm 4.4 \\
\mathbf{0 . 3 5}\end{array}$ & $\begin{array}{l}42.3 \pm 9.5 \\
\mathbf{0 . 4 6}\end{array}$ & $\begin{array}{c}43.0 \pm 7.5 \\
\mathbf{0 . 0 3}\end{array}$ \\
\hline & $\begin{array}{l}2 \text { roots } \\
(\mathrm{n}=6)\end{array}$ & $8.9 \pm 0.3$ & $\begin{array}{c}17.1 \pm 1.9 \\
\mathbf{0 . 3 4}\end{array}$ & $\begin{array}{c}30.2 \pm 1.7 \\
\mathbf{0 . 5 5}\end{array}$ & $\begin{array}{c}45.5 \pm 2.5 \\
\mathbf{0 . 6 4}\end{array}$ & $\begin{array}{c}51.3 \pm 3.1 \\
\mathbf{0 . 2 4}\end{array}$ \\
\hline & $\begin{array}{l}3 \text { roots } \\
(\mathrm{n}=6)\end{array}$ & $8.9 \pm 1.2$ & $\begin{array}{c}23.8 \pm 1.7 \\
\mathbf{0 . 6 2}\end{array}$ & $\begin{array}{c}36.3 \pm 2.4 \\
\mathbf{0 . 5 2}\end{array}$ & $\begin{array}{l}47.5 \pm 5.1 \\
\mathbf{0 . 4 7}\end{array}$ & $\begin{array}{c}47.1 \pm 5.7 \\
-\end{array}$ \\
\hline \multirow{3}{*}{ Collum } & $\begin{array}{l}\text { Control } \\
(n=10)\end{array}$ & $7.2 \pm 0.3$ & $\begin{array}{c}16.6 \pm 0.6 \\
\mathbf{0 . 3 9}\end{array}$ & $\begin{array}{c}33.0 \pm 0.6 \\
\mathbf{0 . 6 8}\end{array}$ & $\begin{array}{c}48.9 \pm 0.9 \\
\mathbf{0 . 6 6}\end{array}$ & $>60$ \\
\hline & $\begin{array}{l}1 \text { root } \\
(n=3)\end{array}$ & $9.5 \pm 0.5$ & $\begin{array}{c}14.8 \pm 2.3 \\
\mathbf{0 . 2 2}\end{array}$ & $\begin{array}{c}21.2 \pm 6.3 \\
\mathbf{0 . 2 7}\end{array}$ & $\begin{aligned} & 26.1 \pm 10.3 \\
& \mathbf{0 . 2 0}\end{aligned}$ & $\begin{array}{c}30.7 \pm 14.2 \\
\mathbf{0 . 1 9}\end{array}$ \\
\hline & $\begin{array}{l}2 \text { roots } \\
(\mathrm{n}=6)\end{array}$ & $7.2 \pm 0.7$ & $\begin{array}{c}14.2 \pm 1.3 \\
\mathbf{0 . 2 9}\end{array}$ & $\begin{array}{c}22.5 \pm 2.6 \\
\mathbf{0 . 3 5}\end{array}$ & $\begin{array}{c}30.2 \pm 3.9 \\
\mathbf{0 . 3 2}\end{array}$ & $\begin{array}{c}36.3 \pm 5.1 \\
\mathbf{0 . 2 5}\end{array}$ \\
\hline
\end{tabular}

*The whole bulb; for other abbreviations. see Table 1. 
It is known that nutrients, which are mainly concentrated in juicy leaves of the bulbs of Allium cepa L., account for $87 \%$ of the bulb mass (open scales $62 \%$, closed scales 25 $\%$ ). Water-soluble carbohydrates, mainly monosaccharides, constitute on the average more than $50 \%$ of the dry substance of juicy scale leaves, whereas disaccharides and fructosanes make up a smaller portion. In addition, bulbs contain flavonoids, glucosides, and thiosulfonates [8-12].

It was shown that, as the bulb exits from rest, active growth processes occur in the collum. High-polymeric structural compounds, such as proteins, nucleic acids, lipids, and others are synthesized in the meristems of the collum and organs developing from them [2].

However, hormonal compounds that ensure the growth and development of plant organs receive little attention [13]. The hormonal regulation of organogenesis in the onion bulb should be associated with the mechanisms of the transport of regulators in the system green leaf-bulbroots. Auxines are often not introduced into nutrient media during the cultivation of individual roots in vitro. Roots under conditions of cultivation are considered to be capable of synthesizing independently some auxines. However, this is characteristic for isolated roots of dicotyledons. There is no agreement regarding the necessity of introducing auxines into the nutrient medium during the cultivation of isolated roots of monocotyledons (maize, rye, wheat) $[14,15]$. The data on the effect of gibberellins and cytokinines on the growth of isolated roots of various plants are also ambiguous [15].

In our experiments, the growth of leaves occurs even with the limited number of roots and after the removal of a part of the bulb. There may be two possible explanation of this: a) even one root is sufficient to produce the required amount of hormones regulating the growth; and b) hormonal regulators necessary for the growth of roots and leaves are synthesized inside the bulb itself.

We conducted the experiments using unchlorinated tap water without the addition of any mineral salts. However, these conditions suffice for the stable growth of roots and leaves even upon the strong reduction of the bulb size.

\section{Acknowledgements}

This work was supported by the Russian Foundation for Basic Research (Project No. 07-04-00510).

\section{REFERENCES}

[1] N. Yarosch and M. N. Ananjina, "Biochemical and Histological Studies of the Bulbs of Allium cepa L.," Bulletin of State Institute of Plant Industry (Russia), Vol. 186, 1988, pp. 28-33.

[2] A. A. Kasakova, I. F. Gavrischova and M. N. Ananjina,
"Anatomical and Histological Characteristics of Structural Parts in Allium cepa L. Bulbs," Bulletin of State Institute of Plant Industry (Russia), Vol. 208, 1991, pp. 24-39.

[3] K. Prasad, V. A. Laxdal, M. Yu and B. L. Raney, "Evolution of Hydroxyl Radical-Scavenging Property of Garlic. Molecular and Cellular Biochemistry, Vol. 154, No. 1, 1996, pp. 55-63. doi:10.1007/BF00248461

[4] A. V. Nefedova and T. L. Kiseleva, "The Onion and Garlic in Phytotherapy and Homoepathy. 2. Chemical Composition of Plant Material," Traditional Medicine (Russia), Vol. 1, No. 2, 2004, pp. 33-41.

[5] A. V. Nefedova and T. L. Kiseleva, "The Onion and Garlic in Phytotherapy and Homoepathy. 4. Some Results of a Study on Regulatory Mechanisms of Biologically Active and Phytopharmaceutical Substances," Traditional Medicine (Russia), Vol. 2, No. 5, 2005, pp. 42-52.

[6] V. D. Eremenko, "Store and Use of Onion and Garlic," Publication "Economics", Moscow, 1965, p. 112.

[7] E. G. Grinberg, V. I. Koschnicaovitch, V. I. Oksienko, M. C. Domanskaya, et al., "Industrial of Onion Bulbs (Allium сера)," Book Publication, Novosibirsk, 1992, pp. 102141.

[8] L. D. Lawson and B. G. Hughes, "Characterization of the Formation of Allicin and Other Thiosulfinates from Garlic," Planta Medica, Vol. 58, No. 4, 1992, pp. 345-350. doi:10.1055/s-2006-961482

[9] B. S. Patil and L. M. Pike, "Distribution of Quercetin Content in Different Rings of Various Colored Onion (Allium cepa L.) Cultivars," The Journal of Horticultural Science, Vol. 70, No. 4, 1995, pp. 643-650.

[10] K. R. Price and M. J. Rhode, "Analysis of the Major Flavanol Glucosides Present in Four Varieties of Onion (Allium сера) and Changes in Composition Resulting from Autolysis," Journal of the Science of Food and Agriculture, Vol. 74, No. 3, 1997, pp. 331-339. doi:10.1002/(SICI)1097-0010(199707)74:3<331::AID-JS FA806>3.0.CO;2-C

[11] S. Hirota, T. Shimoda and U. Takahama, "Tissue and Spatial Distribution of Flavanol and Peroxidase in Onion Bulbs and Stability of Flavanol Glucosides during Boiling of the Scales," Journal of Agricultural and Food Chemistry, Vol. 46, No. 9, 1998.3497-3502. doi:10.1021/jf980294w

[12] D. E. Kopsell, W. M. Randle and M. A. Eiteman, "Changes in the S-alk(en)yl Cysteine Sulfoxides and Their Biosynthetic Intermediates during Onion Storage," Journal of the American Society for Horticultural Science, Vol. 124, No. 2, 1999, pp. 177-183.

[13] H.-W. Heldt, "Plant Biochemistry," Elsevier Academic Press, 2005, pp. 455-489.

[14] J. D. Ferguson, "The Continuous Culture of Excised Wheat Roots," Physiologia Plantarum, Vol. 16, No. 3, 1963, pp. 585-595. doi:10.1111/j.1399-3054.1963.tb08336.x

[15] A. M. Smirnov, "Growth and Metabolism of Root Culture in Sterile Conditions," Publication "Nauka", Moscow, 1970, pp. 313-314. 